Article

\title{
In Vitro Screening of Plant Materials to Reduce Ruminal Protozoal Population and Mitigate Ammonia and Methane Emissions
}

\author{
Pichad Khejornsart ${ }^{1}\left(\mathbb{D}\right.$, Anusorn Cherdthong ${ }^{2, *(\mathbb{D})}$ and Metha Wanapat ${ }^{2}$ (D) \\ 1 Faculty of Natural Resources and Agro-Industry, Kasetsart University Chalermphrakiat Sakon Nakhon \\ Province Campus, Sakon Nakhon 47000, Thailand; fnapck@ku.ac.th \\ 2 Tropical Feed Resources Research and Development Center (TROFREC), Faculty of Agriculture, \\ Khon Kaen University, Khon Kaen 40002, Thailand; metha@kku.ac.th \\ * Correspondence: anusornc@kku.ac.th; Tel.: +66-(0)4-202-362
}

Citation: Khejornsart, P.;

Cherdthong, A.; Wanapat, M. In Vitro Screening of Plant Materials to

Reduce Ruminal Protozoal

Population and Mitigate Ammonia and Methane Emissions. Fermentation 2021, 7, 166. https://doi.org/ $10.3390 /$ fermentation7030166

Academic Editor: Thaddeus Ezeji

Received: 9 July 2021

Accepted: 24 August 2021

Published: 26 August 2021

Publisher's Note: MDPI stays neutral with regard to jurisdictional claims in published maps and institutional affiliations.

Copyright: (c) 2021 by the authors. Licensee MDPI, Basel, Switzerland. This article is an open access article distributed under the terms and conditions of the Creative Commons Attribution (CC BY) license (https:/ / creativecommons.org/licenses/by/ $4.0 /)$.

\begin{abstract}
Alternative feed sources can be utilized to reduce enteric methane $\left(\mathrm{CH}_{4}\right)$ emissions, a major greenhouse gas that contributes to global warming. This study aimed to evaluate the potential use of tropical plants to improve digestibility, reduce protozoal populations, improve rumen fermentation, and minimize methane emissions from ruminants. The plants considered herein grow in tropical climates, are easily accessible in large quantities, and are directly related to human food production. Nine plants that grow naturally in tropical climates were assessed. Plant supplementation substantially enhanced accumulative gas production at $24 \mathrm{~h}(p<0.05)$. The apparent organic matter digestibility (AOMDvt) of the diet was not affected by five of the nine plants. With the addition of the plant material, ammonia nitrogen concentrations were reduced by up to $47 \%$ and methane concentrations were reduced by $54 \%$. Five of the nine plant materials reduced methane production in terms of $\mathrm{CH}_{4}$ /dry matter and $\mathrm{CH}_{4}$ /digestibility of the organic matter by $15-35 \%$ and $8-24 \%$, respectively. In conclusion, supplementation with plants with high tannin contents was shown to be a viable strategy for improving rumen fermentation, reducing protozoal populations, and limiting methane emissions. In this regard, the leaves of Piper sarmentosum, Acmella oleracea, Careya arborea, and Anacardium occidentale were especially promising.
\end{abstract}

Keywords: phytochemical; protozoa; ruminal fermentation; tannins; methanogenesis; ammonia

\section{Introduction}

Livestock production has long been important in agricultural farming in developing countries. It is essential for the production of meat, dairy, and agricultural dung, and has a significant effect on regional stability and improving livelihoods [1]. The animal production industry is thought to contribute up to $16.5 \%$ of global greenhouse gas (GHG) emissions, which have become a major concern in recent decades [2,3]. Enteric fermentation and feed production activities, which account for almost $45 \%$ of the sector's overall emissions, are the main source of GHG emissions in ruminant agriculture [4]. Methane $\left(\mathrm{CH}_{4}\right)$ is the second most important GHG emitted by human activities [5]. Enteric $\mathrm{CH}_{4}$ is produced primarily in the rumen by methanogenic archaea, which convert the hydrogen $\left(\mathrm{H}_{2}\right)$ and carbon dioxide $\left(\mathrm{CO}_{2}\right)$ produced by a diverse community of microorganisms through fermentation [6]. Furthermore, methane production provides for approximately $5-7 \%$ of the feed gross energy, or nearly $16-26 \mathrm{~g} / \mathrm{kg}$ of feed consumed [7], and it is often regarded as a source of energy loss for the animal. As a result, the use of plant secondary metabolites is one of the primary options being investigated for reducing enteric $\mathrm{CH}_{4}$ in this sector [8-10]. Secondary metabolites (tannins, saponins, etc.), which are found in many plant species, were found to have the capacity to modify the rumen methanogenic bacteria population. The use of such feed products may be an effective way to decrease methane 
emissions by improving the overall rumen ecosystem and, as a result, ruminant animal productivity by properly using secondary compounds in tropical plants [11]. Furthermore, tropical regions across the world have a diverse variety of forage resources with favorable chemical compositions that could be used as feed for livestock production systems.

Research into nutrient-rich local resources is critical for improving the cost and efficiency of tropical livestock systems while also reducing their environmental effects. The tropical environment has many natural resources, including fodder trees, shrubs, and herbaceous plants, which have the potential to reduce $\mathrm{CH}_{4}$ emissions from cattle while also recovering deteriorated areas [11,12]. Tropical plants have many uses, including as food flavoring agents, in traditional medicine, and for synthetic insecticides. Certain plant species have been shown to include alkaloids, xanthophylls, polyphenols, lignans, organosulfide, flavonoids, tannin, and saponin. Moreover, the negative effects of flavonoidrich plants on $\mathrm{CH}_{4}$ emissions and methanogenic bacteria were determined in vitro [13] and in vivo $[14,15]$. However, phytochemicals, such as secondary compounds and essential oils, have consistently demonstrated consistent results, varying from a significant reduction to a modest increase in enteric $\mathrm{CH}_{4}$ emissions [16]. The aim of this research was to investigate the in vitro fermentation, protozoal population, and enteric methane mitigation capability of nine plants with high polyphenol or tanniniferous contents.

\section{Materials and Methods}

The study was conducted at the Animal Science Research Unit, the Department of Agriculture and Resources, Kasetsart University Chalermphrakiat Sakon Nakhon Province Campus, Thailand. Animal procedures were approved by the Animal Ethics Committee of Kasetsart University (record no. ACKU64-CSC-004-19/07/2021), based on the Ethic of Animal Experimentation of National Research Council of Thailand.

\subsection{Plant Materials Preparation}

In the present study, plant samples (rhizome, leaves, and tender stems) were hand harvested in Sakon Nakhon Province, Thailand, during the seasons indicated (Table 1). The following nine plant materials were tested: the rhizome of Zingiber officinale (ginger), Alpinia galanga (galanga), Zingiber cassumunar (cassumunar ginger), and Curcuma longa (turmeric); the stem and leaf part of Cymbopogon citratus (lemon grass), Piper sarmentosum (wild pepper), and Acmella oleracea (toothache plant); and the leaf of Careya arborea (Ceylon oak) and Anacardium occidentale (cashew nut). Farmers' plots from three districts, i.e., Sakon Nakhon Province, Maung Sakon Nakhon, Phonnakeaw, and Phuphan, were randomly selected to harvest all plant material. The plant materials were dried at $45^{\circ} \mathrm{C}$ in a hot air oven dryer to a consistent weight before being mashed through a $0.1 \mathrm{~cm}$ mesh (Polymix PX-MFC 90D, Kinematica, Switzerland).

Table 1. The scientific names, plant parts, and harvesting times of the plant samples tested $(n=3)$.

\begin{tabular}{ccccc}
\hline Plant Species. & Plant Family & Common Name & Plant Part & Harvest Time \\
\hline Zingiber officinale Roscoe & Zingiberaceae & Ginger & Rhizome & July \\
Alpinia galanga L. & Zingiberaceae & Galanga & Rhizome & September \\
Cymbopogon citratus & Poaceae & Lemon grass & Stem + Leaf & July \\
Zingiber cassumunar Roxb. & Zingiberaceae & Cassumunar ginger & Rhizome & September \\
Curcuma longa L. & Zingiberaceae & Turmeric & Rhizome & September \\
Piper sarmentosum Roxb. & Piperaceae & Wild pepper & Stem + Leaf & July \\
Acmella oleracea L. & Asteraceae & Toothache plant & Stem + Leaf & May \\
Careya arborea Roxb. & Lecythidaceae & Wild guava, Ceylon oak & Leaf & May \\
Anacardium occidentale L. & Anacardiaceae & Cashew nut & Leaf & May \\
\hline
\end{tabular}




\subsection{Chemical Composition Analysis}

Plant materials, roughage, and concentrate samples were chemically analyzed for dry matter $(\mathrm{DM})$, organic matter $(\mathrm{OM})$, ash, and crude protein $(\mathrm{CP})$, according to the method of AOAC [17]. Neutral detergent fiber (NDF) and acid detergent fiber (ADF) in substrates were determined according to Van Soest et al. [18], adapted to an Ankom Fiber Analyzer A2000 (Ankom Technology Corp., Macedon, NY, USA). Ether extract content was determined using the Soxhlet method. Total phenols (TP) were estimated using the Folin-Ciocalteu reagent method [19]. According to spectrophotometer measurements, the condensed tannin (CT) fraction was determined using the HCl-butanol method described by Terrill et al. [20].

\subsection{Rumen Collection}

In this experiment, three crossbred steers weighing $380 \pm 28 \mathrm{~kg}$ each were used as rumen fluid donors. Total mix ration (TMR) diet (basal diet in Table 2) was offered to the animals at a daily intake of $2.5 \%$ of their body weight (BW). The cattle were provided access to mineral blocks and kept in separate cages with clean water. Rumen fluid was collected using stomach tube with a vacuum pump prior to feeding TMR in the morning (06.00 a.m.), filtered through cheesecloth into warmed flasks, and then transported to the laboratory. Before preparing a batch culture, ruminal fluid from the three cattle was mixed in equal proportions.

Table 2. Ingredients and chemical composition of the basal diet.

\begin{tabular}{|c|c|c|}
\hline Items & Concentrate & Rice Straw \\
\hline \multicolumn{3}{|l|}{ Ingredients (\% DM) } \\
\hline Cassava chips & 58.5 & \\
\hline Rice bran & 14.0 & \\
\hline Palm kernel meal & 14.0 & \\
\hline Soy bean meal & 6.0 & \\
\hline Mineral mixed * & 1.0 & \\
\hline Sulfur & 1.0 & \\
\hline Urea & 1.5 & \\
\hline Salt & 1.0 & \\
\hline Molasses & 3.0 & \\
\hline \multicolumn{3}{|l|}{ Chemical composition } \\
\hline Dry matter (\%) & 93.5 & 94.5 \\
\hline Organic matter (\% DM) & 92.7 & 93.1 \\
\hline Crude protein (\% DM) & 14.0 & 2.8 \\
\hline Neutral detergent fiber (\% DM) & 12.5 & 65.8 \\
\hline Acid detergent fiber (\% DM) & 8.9 & 43.3 \\
\hline
\end{tabular}

\subsection{In Vitro Gas Production}

The in vitro method described by Menke and Steingass [21] was used to estimate gas production. Two sets of modified $100 \mathrm{~mL}$ glass syringes were used for incubation: one for fluid sampling and the other for gas sampling. In this study, $15 \mathrm{mg}$ of plant material were supplemented into $200 \mathrm{mg}$ of basal diet (in DM basis). TMR (basal diet) was comprised of rice straw and concentrate in a 70:30 ratio (Table 2). Samples with plant supplementation were accurately weighed into $100 \mathrm{~mL}$ glass syringes fitted with plungers. The solution was then dissolved in a 1:2 ratio with a buffer according to Menke and Steingass' technique [21]. In the laboratory, the obtained solutions were mixed together in one beaker under a continuous stream of $\mathrm{CO}_{2}$ and maintained in a water bath at $39^{\circ} \mathrm{C}$ before being added to the syringes. Rumen liquid was filtered through four layers of gauze and mixed in a 1:2 ratio with a buffer solution according to Menke and Steingass' technique [21]. For each treatment, $30 \mathrm{~mL}$ of rumen fluid-buffer mixture was loaded into 
syringes (six runs per plant material sample). Each run contained a duplicate of blanks and two syringes, with the basal diet as a negative control for a total of 64 incubations.

\subsection{In Vitro Rumen Fermentation Characteristics}

The syringes were put into a $39{ }^{\circ} \mathrm{C}$ incubator, and the accumulative gas volume was measured using the calibrated scale written on the syringes after 2, 4, 8, 12, 24, 36, and $48 \mathrm{~h}$ of incubation. The data for cumulative gas were fitted to Ørskov and McDonald's model [22]. $\mathrm{A} \mathrm{pH}$ meter was used to measure the $\mathrm{pH}$ of the incubation solution immediately after collection ( $\mathrm{pH}$ : HI 8424 microcomputer $\mathrm{pH}$ meter, Singapore). After $24 \mathrm{~h}$ of inoculation, the incubation liquid was collected and analyzed for ammonia nitrogen $\left(\mathrm{NH}_{3}-\mathrm{N}\right)$ content [17], with only distillation and titration steps. The concentration of volatile fatty acid (VFA) was analyzed using high-performance liquid chromatography (Agilent 1200 series, Agilent Technologies Inc. Santa Clara, CA, USA) with a diode array detector (Zorbax Eclipse XDB-C18 column $(4.6 \times 150 \mathrm{~mm}, 5 \mu \mathrm{m}))$ using $0.1 \mathrm{M}$ phosphate buffer as the mobile phase. A total of $150 \mu \mathrm{L}$ of fermentation gas was collected from the incubation syringes and injected into a gas chromatograph using a gas-tight Hamilton syringe (Agilent Technologies Inc. 5977B Single Quadrupole, Bellefonte, PA, USA) with the following specifications: Carboxen 1000, 45/60, 2 m 1/8" (Supelco, Bellefonte, PA, USA) column with flame ionization detector. In vitro digestibility was determined after $24 \mathrm{~h}$ of incubation when the contents were filtered through pre-weighed Gooch crucibles and residual dry matter was measured after $48 \mathrm{~h}$ of oven drying at $60^{\circ} \mathrm{C}$. The residual sample from each was utilized for AOMDvt following Tilley and Terry's method [23]. Net energy for lactation $\left(\mathrm{NE}_{\mathrm{L}}\right)$ was estimate using the equation of Menke and Steingass [21] as given below (Equation (1)).

$$
\mathrm{NE}_{\mathrm{L}}(\mathrm{MJ} / \mathrm{kg} \mathrm{DM})=-0.22+0.1062 \mathrm{GP}+0.048 \mathrm{CP}+0.1329 \mathrm{EE}
$$

where GP denotes $24 \mathrm{~h}$ of net gas production $(\mathrm{mL} / 200 \mathrm{mg})$, CP denotes crude protein $(\%)$, and EE denotes ether extract (\%).

\subsection{Bacterial and Protozoal Count}

After $24 \mathrm{~h}$ of fermentation, a $1 \mathrm{~mL}$ sample of the incubation liquid was immediately added to $6 \mathrm{~mL}$ of $10 \%$ formaldehyde. The population of protozoa and bacteria were determined using the method of Galyean [24]. The incubation fluid was diluted with 10 times the amount of autoclaved distilled water and protozoa and bacteria were counted with a hemacytometer (Boeco, Hamburg, Germany) and under a light microscopic (150×) (Olympus BX51-DIC-B, Olympus Optical Co. Ltd., Tokyo, Japan).

\subsection{Statistical Analysis}

All data were obtained using the SAS general linear model procedure (SAS Institute Inc., Cary, NC, USA). Tukey's test was used to examine differences between treatment means, and differences between means with $p<0.05$ were considered statistically significant. The statistical model and experimental design were as follows:

$$
Y i j=\mu+M i+\varepsilon i j
$$

where Yij denotes the observation variable, $\mu$ denotes the overall mean, $\mathrm{M}$ denotes the influence of the plant material ( $\mathrm{i}=1-9)$, and $\varepsilon$ ij denotes the residual effect. The incubation run $(n=6)$ was categorized as a random effect $(n=6)$, whereas the plant material (including the basal diet alone) was classified as a fixed effect $(n=10)$.

\section{Results}

\subsection{Chemical Analyses of Plant Materials}

Table 3 shows the chemical analysis of the plant materials used in this study. The crude protein levels varied from 54.8 to $234.5 \mathrm{~g} / \mathrm{kg}$ DM. The highest levels were detected in Acmella oleracea (234.5 g/ $\mathrm{kg} \mathrm{DM})$ and the lowest in Zingiber officinale (76.9 g/ $\mathrm{kg} \mathrm{DM})$. 
EE was found in small quantities in Anacardium occidentale (11.9 g/ $\mathrm{kg} D M)$, followed by Cymbopogon citratus ( $18.7 \mathrm{~g} / \mathrm{kg} \mathrm{DM}$ ); in contrast, almost eight times as much EE was detected in Curcuma longa (about $80 \mathrm{~g} / \mathrm{kg}$ DM). NDF and ADF levels were highest in Cymbopogon citratus (649.4 and $424.0 \mathrm{~g} / \mathrm{kg} \mathrm{DM}$ ), followed by Piper sarmentosum (647.2 and $398.6 \mathrm{~g} / \mathrm{kg} \mathrm{DM}$ ), and lowest in Curcuma longa rhizome (404.9 and $131.9 \mathrm{~g} / \mathrm{kg} \mathrm{DM})$. Among all the plant materials, Careya arborea and Anacardium occidentale had the highest CT content (159.2 and $165.7 \mathrm{~g} / \mathrm{kg}$ DM, respectively), whereas Alpinia galangal had the highest TP levels (385.4 g/kg DM).

Table 3. Chemical composition of the plant samples tested $(n=3)$.

\begin{tabular}{cccccccc}
\hline \multirow{2}{*}{ Scientific Names } & \multicolumn{7}{c}{ Chemical Composition (g/kg DM) } \\
\cline { 2 - 7 } & OM & CP & EE & NDF & ADF & CT & TP \\
\hline Zingiber officinale & 832.2 & 76.9 & 63.6 & 563.2 & 369.7 & 27.6 & 155.8 \\
Alpinia galanga & 831.5 & 81.8 & 68.1 & 625.0 & 368.1 & 63.9 & 385.4 \\
Cymbopogon citratus & 897.4 & 54.8 & 18.7 & 649.4 & 427.0 & 15.4 & 24.6 \\
Zingiber cassumunar & 957.0 & 136.2 & 58.8 & 423.8 & 184.7 & 14.0 & 236.4 \\
Curcuma longa & 952.5 & 104.7 & 78.8 & 404.9 & 131.9 & 29.4 & 289.6 \\
Piper sarmentosum & 940.1 & 188.5 & 63.9 & 647.2 & 398.6 & 89.3 & 91.2 \\
Acmella oleracea & 946.8 & 234.5 & 52.2 & 434.1 & 189.3 & 104.1 & 135.7 \\
Careya arborea & 966.0 & 150.3 & 59.8 & 514.1 & 309.3 & 159.2 & 201.5 \\
Anacardium occidentale & 928.3 & 97.5 & 11.9 & 458.4 & 391.5 & 165.7 \\
\hline
\end{tabular}

OM: organic matter; CP: crude protein; EE: ether extract; NDF: neutral detergent fiber; ADF: acid detergent fiber; CP: crude protein; CT: condense tannins; TP: total phenol.

\subsection{In Vitro Gas Production Parameters}

The gas production kinetic parameters and cumulative gas production parameters at $48 \mathrm{~h}$ of incubation are shown in Table 4 . The quantity of gas produced from the rapidly soluble fractions (a), the amount of gas produced from the insoluble fraction (b), and the potential extent of gas produced $(a+b)$ all varied considerably $(p<0.05)$. The insoluble fraction (c) gas production rate constants, on the other hand, exhibited no statistically significant influence when plant materials were added $(p>0.05)$. Adding Zingiber cassumunar and Curcuma longa to a $200 \mathrm{mg}$ basal diet lowered the kinetic gas parameters. After $48 \mathrm{~h}$ of incubation, a similar pattern was found in cumulative gas generation, which was statistically enhanced when tree leaf foliage was added $(p<0.05)$; however, rhizomes in the substrate lowered the cumulative gas production.

Table 4. The effect of plant supplementation on the in vitro gas kinetics and cumulative gas production at $48 \mathrm{~h}$ after incubation.

\begin{tabular}{cccccc}
\hline \multirow{2}{*}{ Treatments } & \multicolumn{4}{c}{ Gas Production Kinetic Parameters } & Cumulative Gas (mL/48 h) \\
\cline { 2 - 5 } & $\mathbf{a}$ & $\mathbf{b}$ & $\mathbf{c}$ & $\mathbf{a}+\mathbf{b}$ & \\
\hline Basal diet & $2.07^{\mathrm{ab}}$ & $102.60^{\mathrm{f}}$ & 0.062 & $104.53^{\mathrm{d}}$ & $99.80^{\mathrm{e}}$ \\
Zingiber officinale & $3.05^{\mathrm{bc}}$ & $78.44^{\mathrm{bc}}$ & 0.060 & $81.49^{\mathrm{b}}$ & $80.15^{\mathrm{b}}$ \\
Alpinia galanga & $1.36^{\mathrm{a}}$ & $73.96^{\mathrm{ab}}$ & 0.052 & $75.42^{\mathrm{a}}$ & $72.90^{\mathrm{a}}$ \\
Cymbopogon citratus & $2.02^{\mathrm{ab}}$ & $84.22^{\mathrm{c}}$ & 0.050 & $86.42^{\mathrm{b}}$ & $84.95^{\mathrm{c}}$ \\
Zingiber cassumunar & $1.35^{\mathrm{a}}$ & $72.04^{\mathrm{a}}$ & 0.034 & $73.39^{\mathrm{a}}$ & $70.40^{\mathrm{a}}$ \\
Curcuma longa & $1.74^{\mathrm{a}}$ & $72.86^{\mathrm{a}}$ & 0.030 & $73.59^{\mathrm{a}}$ & $70.70^{\mathrm{a}}$ \\
Piper sarmentosum & $1.91^{\mathrm{a}}$ & $80.74^{\mathrm{c}}$ & 0.043 & $82.65^{\mathrm{b}}$ & $81.90^{\mathrm{b}}$ \\
Acmella oleracea & $3.41^{\mathrm{c}}$ & $96.42^{\mathrm{e}}$ & 0.048 & $99.83^{\mathrm{d}}$ & $98.40^{\mathrm{e}}$ \\
Careya arborea & $2.18^{\mathrm{ab}}$ & $80.69^{\mathrm{c}}$ & 0.060 & $82.79^{\mathrm{b}}$ & $80.50^{\mathrm{b}}$ \\
Anacardium occidentale & $2.32^{\mathrm{ab}}$ & $90.55^{\mathrm{d}}$ & 0.054 & $92.87^{\mathrm{c}}$ & $91.55^{\mathrm{d}}$ \\
SEM & 0.325 & $1.705^{\mathrm{b}}$ & 0.011 & 1.723 & 0.956 \\
\hline
\end{tabular}

${ }^{\text {a-f }}$ Significant difference with $p<0.05$; SEM: standard error of the mean. 


\subsection{In Vitro Rumen Fermentation, Bacterial, and Protozoal Population Characteristics}

After a 24-h incubation period, the fermentation fluid had a $\mathrm{pH}$ range of 6.6-6.9. Table 5 shows that all plant materials reduced $\mathrm{NH}_{3}-\mathrm{N}$ concentrations by $47 \%$ as compared to the basal diet, especially when Anacardium occidentale was supplemented $(p<0.05)$. The bacterial count was affected by certain plant materials $(p<0.05)$, e.g., a high count was observed with Cymbopogon citratus meal and a low count was observed with Curcuma longa. Protozoal counts were significantly decreased as a result of all plant materials supplements when compared to the basal diet; however, Zingiber officinale did not have an effect $(p<0.05)$. The total volatile fatty acid (TVFA) concentration decreased after supplementation with all plant materials $(p<0.05)$. The propionate $(\mathrm{C} 3)$ proportion in plant material additives was significantly altered, particularly in Cymbopogon citratus, Acmella oleracea, and Careya arborea, but acetate (C2) and butyrate (C4) were not changed as compared to the basal diet. Curcuma longa had the greatest acetate to propionate (C2:C3) ratio (3.78), while Careya arborea had the lowest at $3.39(p<0.05)$.

Table 5. The effects of basal diet as a control substrate and plant supplementation on ruminal fermentation parameters.

\begin{tabular}{|c|c|c|c|c|c|c|c|c|}
\hline \multirow{2}{*}{ Plant Species } & \multirow{2}{*}{$\begin{array}{l}\text { Ammonia } \\
(\mathrm{mg} / \mathrm{dL})\end{array}$} & \multirow{2}{*}{$\begin{array}{l}\text { Total Bacteria } \\
\qquad\left(10^{9} / \mathrm{mL}\right)\end{array}$} & \multirow{2}{*}{$\begin{array}{l}\text { Total Protozoa } \\
\quad\left(10^{4} / \mathrm{mL}\right)\end{array}$} & \multicolumn{5}{|c|}{$\begin{array}{l}\text { SCFA (mmol/dL) and the Molar Proportions } \\
\qquad(\mathrm{mmol} / 100 \mathrm{~mol})\end{array}$} \\
\hline & & & & TVFA & $\mathrm{C} 2$ & $\mathrm{C} 3$ & $\mathrm{C} 4$ & $\mathrm{C} 2 / \mathrm{C} 3$ \\
\hline Basal diet & $13.98^{c}$ & $5.76^{\mathrm{c}}$ & $5.73^{c}$ & $94.19^{c}$ & 69.61 & $18.24^{\mathrm{a}}$ & 11.85 & $3.75^{\mathrm{d}}$ \\
\hline Zingiber officinale & $9.85^{\mathrm{ab}}$ & $4.48^{\mathrm{bc}}$ & $4.96^{\mathrm{bc}}$ & $87.64^{\mathrm{ab}}$ & 69.75 & $18.98^{a b c}$ & 11.27 & $3.67^{b c d}$ \\
\hline Alpinia galanga & $8.94^{\mathrm{ab}}$ & $4.82 \mathrm{bc}$ & $4.32^{b}$ & $85.60^{a}$ & 69.80 & $18.69^{a b c}$ & 11.51 & $3.73^{\mathrm{cd}}$ \\
\hline Cymbopogon citratus & $9.45^{\mathrm{ab}}$ & $5.05 \mathrm{bc}$ & $2.25^{\mathrm{a}}$ & $88.78^{a b}$ & 69.20 & $19.65 \mathrm{bc}$ & 11.15 & $3.52^{a b}$ \\
\hline Zingiber cassumunar & $9.52^{\mathrm{ab}}$ & $3.14^{\mathrm{b}}$ & $2.64^{\mathrm{a}}$ & $86.28^{a b}$ & 69.96 & $18.42^{\mathrm{ab}}$ & 11.62 & $3.80^{\mathrm{d}}$ \\
\hline Curcuma longa & $10.70^{b}$ & $1.26^{\mathrm{a}}$ & $2.04^{\mathrm{a}}$ & $85.15^{\mathrm{a}}$ & 69.56 & $18.40^{\mathrm{ab}}$ & 12.04 & $3.78^{\mathrm{d}}$ \\
\hline Piper sarmentosum & $9.38^{a b}$ & $4.46^{\mathrm{bc}}$ & $2.88^{a}$ & $89.30^{b c}$ & 68.93 & $19.54 \mathrm{abc}$ & 11.53 & $3.53^{a b c}$ \\
\hline Acmella oleracea & $9.78^{a b}$ & $5.00 \mathrm{bc}$ & $2.91^{\mathrm{a}}$ & $85.48^{a}$ & 68.31 & $19.72 b c$ & 10.97 & $3.46^{\mathrm{a}}$ \\
\hline Careya arborea & $8.59^{a b}$ & $3.75^{b}$ & $2.72^{a}$ & $90.5^{b c}$ & 68.96 & $20.29^{c}$ & 10.75 & $3.39^{\mathrm{a}}$ \\
\hline Anacardium occidentale & $7.39^{a}$ & $4.25 \mathrm{bc}$ & $2.33^{a}$ & $84.58^{\mathrm{a}}$ & 69.18 & $18.62^{a b}$ & 12.20 & $3.72 \mathrm{bcd}$ \\
\hline SEM & 0.741 & 0.582 & 0.439 & 1.395 & 0.634 & 0.487 & 0.351 & 0.063 \\
\hline
\end{tabular}

a-d Significant difference $p<0.05$; SCFA: short-chain fatty acids; TVFA: total volatile fatty acids; C2: acetate; C3: propionate; C4: butyrate; C2/C3: acetate/propionate ratio; SEM: standard error of the mean.

\subsection{In Vitro Apparent OM Digestibility, Methane Production, and Net Energy for Lactation}

In comparison to the basal diet, supplementation with plant materials had no effect on total gas production during the 24-h incubation period. Supplementation with Curcuma longa, Careya arborea, and Anacardium occidentale, on the other hand, considerably reduced the total gas volume $(p<0.05)$. In vitro apparent organic matter digestibility (AOMDvt) and the amount of organic matter (OM) digested in $24 \mathrm{~h}$ both decreased with the addition of Curcuma longa, Acmella oleracea, Careya arborea, and Anacardium occidentale $(p<0.05)$ (Table 6). In comparison to the control, all plant material supplements reduced methane $\left(\mathrm{CH}_{4}\right)$ production per digested unit of $\mathrm{OM}(\mathrm{dOM})(p<0.05)$. Methane production per unit of ingested $\mathrm{OM}$ and total $\mathrm{CH}_{4}$ production in $\mathrm{mL} / 24 \mathrm{~h}$ were both similar. Zingiber officinale had the smallest effect; whereas Acmella oleracea and Careya arborea had the greatest $\mathrm{CH}_{4}$-mitigating effect. The $\mathrm{CH}_{4}$ to TVFA ratio was dramatically lowered as a result of all plant materials, with the addition of Careya arborea yielding the lowest value $(p<0.05)$ (Table 4). Supplementing four plant materials to a level ranging from 0.47 (Careya arborea) to 0.79 (Anacardium occidentale) $\mathrm{MJ} / \mathrm{kg}$ DM reduced the $\mathrm{NE}_{\mathrm{L}}$ content of the basal diet (Table 6). 
Table 6. The effects of plant supplementation with basal diet on gas production, in vitro apparent organic matter digestibility, methane production, and $\mathrm{NE}_{\mathrm{L}}$ content in $\mathrm{DM}$.

\begin{tabular}{|c|c|c|c|c|c|c|c|}
\hline Plant Species & $\begin{array}{l}\text { Total Gas } \\
(\mathrm{mL} / 24 \mathrm{~h})\end{array}$ & $\begin{array}{l}\text { AOMDvt } \\
(\%)\end{array}$ & $\begin{array}{c}\text { dOM } \\
(\mathrm{mg} / 24 \mathrm{~h})\end{array}$ & $\begin{array}{c}\mathrm{CH}_{4} / \mathrm{OM} \\
(\mathrm{mL} / \mathrm{g})\end{array}$ & $\begin{array}{c}\mathrm{CH}_{4} \\
(\mathrm{~mL} / 24 \mathrm{~h})\end{array}$ & $\begin{array}{l}\mathrm{CH}_{4} / \text { TVFA } \\
(\mathrm{mmol} / \mathrm{mol})\end{array}$ & $\begin{array}{c}\mathrm{NE}_{\mathrm{L}} \\
(\mathrm{MJ} / \mathrm{kg} \mathrm{DM})\end{array}$ \\
\hline Basal diet & $69.24^{\mathrm{cd}}$ & $67.62^{c}$ & $135.24^{\mathrm{c}}$ & $57.01^{\mathrm{f}}$ & $7.71^{\mathrm{e}}$ & $132.19^{\mathrm{e}}$ & $5.16^{\mathrm{d}}$ \\
\hline Zingiber officinale & $75.20^{d}$ & $67.28^{c}$ & $134.56^{\mathrm{c}}$ & $50.16^{\mathrm{e}}$ & $6.75^{\mathrm{d}}$ & $116.09^{\mathrm{d}}$ & $4.68^{\mathrm{abc}}$ \\
\hline Alpinia galanga & $70.78^{\mathrm{cd}}$ & $66.55^{c}$ & $133.10^{\mathrm{cd}}$ & $38.47^{c}$ & $5.12^{\mathrm{c}}$ & $110.45^{c}$ & $5.21^{\mathrm{d}}$ \\
\hline Cymbopogon citratus & $66.80^{c}$ & $66.80^{c}$ & $133.60^{\mathrm{cd}}$ & $39.75^{c}$ & $5.31^{\mathrm{c}}$ & $108.88^{c}$ & $4.50^{\mathrm{ab}}$ \\
\hline Zingiber cassumunar & $65.88^{c}$ & $65.89 \mathrm{bc}$ & $131.78^{\mathrm{bcd}}$ & $32.79^{b}$ & $4.32^{b}$ & $100.04^{\mathrm{a}}$ & $5.06^{\mathrm{cd}}$ \\
\hline Curcuma longa & $58.09 \mathrm{ab}$ & $59.96^{a}$ & $119.92^{a}$ & $43.95^{\mathrm{d}}$ & $5.27^{\mathrm{c}}$ & $110.96^{c}$ & $4.96^{\mathrm{cd}}$ \\
\hline Piper sarmentosum & $65.95^{c}$ & $64.50^{b}$ & $129.01 \mathrm{bc}$ & $33.64^{b}$ & $4.34^{\mathrm{b}}$ & $104.57^{b}$ & $4.92^{\mathrm{bcd}}$ \\
\hline Acmella oleracea & $63.80^{b c}$ & $63.84^{b}$ & $127.68^{b}$ & $28.52^{\mathrm{a}}$ & $3.64^{\mathrm{a}}$ & $101.65^{\mathrm{ab}}$ & $5.00^{\mathrm{cd}}$ \\
\hline Careya arborea & $53.67^{\mathrm{a}}$ & $59.85^{\mathrm{a}}$ & $119.70^{\mathrm{a}}$ & $29.49^{a}$ & $3.53^{\mathrm{a}}$ & $99.29^{a}$ & $4.69^{a b c}$ \\
\hline Anacardium occidentale & $53.92^{\mathrm{a}}$ & $58.96^{\mathrm{a}}$ & $117.92^{\mathrm{a}}$ & $32.74^{b}$ & $3.86^{\mathrm{ab}}$ & $104.71^{b}$ & $4.37^{\mathrm{a}}$ \\
\hline SEM & 0.824 & 0.761 & 1.523 & 0.695 & 0.194 & 1.145 & 0.135 \\
\hline
\end{tabular}

${ }^{\mathrm{a}-\mathrm{f}}$ Significant difference $p<0.05 ; \mathrm{CH}_{4}$ : methane; AOMDvt: apparent organic matter digestibility in vitro [25]; dOM: digestibility of organic matter; TVFA: total volatile fatty acids; SEM: standard error of the mean.

\section{Discussion}

\subsection{Chemical Analyses of Plant Materials}

In the concentrate diet, cassava chips were utilized as an energy source, providing $58.5 \%$ of the $\mathrm{DM}$, and urea was used as a fermentable nitrogen source $(1.5 \% \mathrm{DM})$. A substrate containing rice straw $(\mathrm{CP}$ at $2.8 \% \mathrm{DM})$ was used as a roughage source, and the concentrate diet comprised $14.0 \% \mathrm{CP}$. Carious factors, including species, season, and geographical zone, can alter the composition of woody plants, which vary considerably in terms of nutritional and CT content, and methanogenesis capacity [26]. Tannin and total phenolic component concentrations in plant material may impact the protozoal population and rumen fermentation (Table 5). Research into natural resources with high nutritional values is important for enhancing the profitability and productivity of livestock systems in tropical regions, and reducing their environmental impact $[8-10,12-14]$. Several mitigation strategies are associated with an increase in animal production efficiency based on various nutritional and environmental improvements [27]. Furthermore, as a result of the obvious strong interest in CT biological activity in the bovine habitat, it is important to mention that not all forms of CT are beneficial for ruminant nutrition. Anacardium occidentale had the greatest CT content $(165.7 \mathrm{~g} / \mathrm{kg} \mathrm{DM})$ in our study, followed by Careya arborea $(159.2 \mathrm{~g} / \mathrm{kg} \mathrm{DM})$ and Acmella oleracea $(104.1 \mathrm{~g} / \mathrm{kg}$ DM). Despite having a higher CT content than the other plants investigated, Anacardium occidentale did not produce the best biological effect. Various plants, particularly the ginger plant or the Zingiberaceae family, are widely used as a spice and flavoring agent in foods, but can also be added to animal feed to improve productivity, e.g., as a flavoring, to increase digestion and performance, for stress management, to enhance animal welfare, for example, in the form of odor stabilizers, to improve the local environment, and as antibacterial agents, such as is the case for certain essential oils that can replace in-feed antibiotics $[27,28]$.

\subsection{In Vitro Gas Production Parameters}

It has been demonstrated that the availability of nutrients in plant material stimulates kinetic gas production. This was supposed to be attributed in part to the availability of plant material in the mixture, which supplied soluble carbohydrates (molasses) and protein (urea). This was thought to be when the basal diet included plant material, which provided soluble carbohydrates (molasses) and protein (urea). In vitro gas production has been shown to be a more efficient method of evaluating tannin effects than in sacco and is an indirect measure of substrate degradation $[29,30]$. The effects of tannins from diverse sources on ruminal gas production and ammonia quantities have been studied [31]. There was a consistent increase in gas production over a 48 -h period; moreover, there were 
significant differences in the total gas volume between plant supplementations (Table 4). Supplements with low tannin levels provided the most net gas, whereas additions with higher tannin levels produced the lowest. Getachew et al. [32] and Terranova et al. [33] demonstrated strong connections between $\mathrm{CT}$ and gas production, and their findings are consistent with ours. According to Cherdthong et al. [13], a positive correlation between gas production and high-CT pellet supplementation could be due to microbial activity stimulation caused by increased adverse microbiological conditions. The lower gas output for tannin treatments as compared to the control indicated that high tannin levels in plant material supplements limited ruminal carbohydrate fermentation [34]. This finding was enhanced in part by the fact that high-CT plant materials supplementation resulted in significantly lower VFA concentrations. However, high CT and TP contents in plant materials in the substrate may have a negative effect on rumen microbial activity, decreasing gas kinetics and production [33,35].

\subsection{In Vitro Rumen Fermentation, Bacteria, and Protozoal Population Characteristics}

The plant supplementation had an in vitro ruminal $\mathrm{pH}$ of 6.6-6.9, which was within the typical range of ruminal $\mathrm{pH}$ of 5.5-7.0. In contrast to the control, increased tannin in the plant materials decreased TVFA concentrations, which is in accordance with the findings of Wanapat et al. [14] and Min et al. [36]. Reduced $\mathrm{NH}_{3}-\mathrm{N}$ concentrations indicate increased nitrogen utilization by rumen bacteria for MCP production. The first case was substantiated by the lower molar proportions of branch chain volatile fatty acids, i.e., end products of the deamination of feed amino acids, in plant supplementation as compared to the control; the second case was supported by the higher MCP concentrations in the supplementation as compared to the control. Moreover, Aderinboye and Olanipekun [37] found that turmeric inclusion above $5 \mathrm{mg} / \mathrm{g}$ DM of substrate can modify the rumen by causing a reduction in fermentation end products, and a reduction in ammonia production at $15 \mathrm{mg} / \mathrm{g}$, which significantly reduced microbial biomass, has implications for lowering microbial protein synthesis. In this study, both occurrences were confirmed in the plant materials with high tannin contents. Similarly, decreasing ruminal protozoal populations were related to $\mathrm{CT}$ and $\mathrm{TP}$ contents in plant material supplementations, particularly the addition of Curcuma longa, which reduced protozoa by $64 \%$ when compared to a basal diet. Methane production was negligible as compared to protozoal number. The protozoal population was reduced (Table 5) and methane production was decreased by supplementing with plant materials with high CT and TP concentrations in the fermentation substrate (Table 6). This finding was consistent with those of Sarnataro et al. [38], who found that adding Stevia rebaudiana Bertoni extract and chestnut wood tannin to the rumen reduced the in vitro protozoal population while having no effect on the fermentation parameters; whereas Jayanegara et al. [39] found dietary tannins had no effect on protozoal numbers in an in vitro study. Newbold et al. [40] recommended complete rumen protozoal elimination as a means to increase microbial protein supply by $30 \%$ while reducing methane production by up to $11 \%$. However, Dai and Faciola [41] recommended partial rumen protozoal reduction strategies, and tannin supplementation, to reduce methane production. Plant material supplementation resulted in reduced TVFA concentrations, supporting the findings of Min et al. [36] concerning lower TVFA concentrations as compared to the control. This could be the result of decreased DM and NDF degradation as was shown by Chen et al. [34]. In the present study, nine of the plant additives resulted in a higher proportion of propionate, while practically all of the plant additives had no effect on the proportions of acetate and butyrate. As a result, these nine plant components reduced the acetate-to-propionate ratio. This study found an increase in propionate, which is similar to the findings of Cieslak et al. [42] who focused on Vaccinium vitis idaea extract supplementation, Wang et al. [43] who focused on Atractylodes rhizome and Amur cork tree supplementation, and Chen et al. [34] who focused on tannins. Propionate synthesis and methanogenesis are two competing processes for hydrogen metabolism in the rumen. As a result, processes that increase propionate may result in decreased methanogenesis, as was demonstrated 
by the findings of this study. Furthermore, Zhou et al. [44] reported that feeding Piper sarmentosum extract at $1200 \mathrm{mg} / \mathrm{kg}$ decreased the ratio of acetate to propionate and reduced the population of protozoa, fungi, Ruminococcus flavefaciens, and Fibrobacter succinogenes in goats.

\subsection{In Vitro Apparent OM Digestibility, Methane Production, and Net Energy for Lactation}

The inclusion of plant materials had no effect on total gas production throughout the 24-h incubation period in the current study. Furthermore, AOMDvt was comparable to that of the basal diet for several of the plant supplements. AOMDvt and total gas production were likewise lowest in plant materials with the lowest TVFA content. This may be related to the total bacteria and TVFA formation, as shown in Table 5. However, Akanmu et al. [45] observed that using plant extracts increased AOMDvt, while Cieslak et al. [42] showed that utilizing Vaccinium vitis idaea extract decreased methane without interfering with feed digestibility. According to Cielak et al. [46], plant secondary metabolites reduce nutrient digestibility, but only at higher levels of Sanguisorba officinalis supplementation. Nevertheless, Akanmu et al. [47] observed that plant extracts had a significant defaunating impact in the rumen, increasing the richness of bacteria, ruminal cellulolytic, and fungus populations. The reduction in ruminal fibrolytic bacterial populations caused tannins and saponins to have an inhibitory effect on nutrient digestion [27,34,44]. The addition of plant materials rich in $\mathrm{CT}$ and TP to ruminant feed is a promising strategy for reducing $\mathrm{CH}_{4}$ emissions. Supplementation with Careya arborea reduced the $\mathrm{CH}_{4}$-mitigating influence of the plant materials used in this study by up to $54 \%$, which was much more pronounced than Cherdthong et al. $[13,15]$ reported. This may be due to the difference in the basal diet. Similarly, supplementing the basal diet with these plant materials resulted in low $\mathrm{NE}_{\mathrm{L}}, \mathrm{CH}_{4} / \mathrm{OM}$, and $\mathrm{CH}_{4} / \mathrm{TVFA}$ levels. Regardless of the fact that methanogenic archaea use $\mathrm{H}_{2}$ and $\mathrm{CO}_{2}$ as substrates to produce ruminal $\mathrm{CH}_{4}$, it is generally known that tannins can reduce ruminal $\mathrm{CH}_{4}$ production in two ways: (1) by inhibiting the activity of several rumen microbes affected in $\mathrm{CH}_{4}$ production; and (2) by reducing carbohydrate digestion by forming stable complexes with carbohydrates [48-50]. Chen et al. [34] found that plant extracts containing both HT and CT had a stronger capacity to decrease methanogenesis than those containing only HT. The current study's reduction in $\mathrm{CH}_{4}$ revealed that plants known to contain secondary metabolites are capable of inhibiting methanogenesis, and this was most probably due to a reduction in fiber degradation $[50,51]$.

\section{Conclusions}

Methane formation per unit of digestible OM was reduced by five out of the nine plant materials as compared with the basal diet. Moreover, all materials decreased ammonia formation. The majority of the plant supplements tested had no adverse effect on in vitro digestibility. Plant materials, such as the leaves of Piper sarmentosum, Acmella oleracea, Careya arborea, and Anacardium occidentale, should be used as primary substrates in future in vitro investigations. Furthermore, future in vivo experiments should focus on the palatability of plant materials, confirm their mitigating effects, and evaluate their effect on production.

Author Contributions: Authors all made considerable contributions to the conception and design, M.W., P.K. and A.C.; data collection, review and evaluation of the data, P.K.; assisted in the writing or revision of the paper P.K. and A.C.; crucial to significant intellectual content P.K.; agreed to submit it to the current journal M.W. and A.C.; gave final approval to the version to be published, P.K.; and agreed to be responsible for all aspects of the work, M.W. and A.C. All authors have read and agreed to the published version of the manuscript.

Funding: The authors are grateful to the Post-Doctoral Training from Research and Graduate Studies, Khon Kaen University (KKU) (PD 2563-02-18), Research Program on the Research and Development of Winged Bean Root Utilization as Ruminant Feed and the Increase Production Efficiency and Meat Quality of Native Beef and Buffalo Research Group for granting funding for the research. 
Institutional Review Board Statement: Approval no. ACKU64-CSC- 004-19/07/2021 was issued by the Animal Ethics Committees of Kasetsart University.

Informed Consent Statement: Not applicable.

Data Availability Statement: Not applicable.

Acknowledgments: The authors greatly acknowledge the Tropical Feed Resources Research and Development Center (TROFREC), Faculty of Agriculture, Khon Kaen University and the Department of Agricultural and Resources, Faculty of Natural Resources and Agro-Industry, Kasetsart University, Chalermphrakiat Sakon Nakhon Province Campus, Thailand for providing research facilities support. All technical assistance offered by scientists and grade students from the Department of Agriculture and Resources is greatly valued.

Conflicts of Interest: The authors confirm that they have no conflict of interest to declare for this publication.

\section{References}

1. Wanapat, M.; Kang, S.; Polyorach, S. Development of feeding systems and strategies of supplementation to enhance rumen fermentation and ruminant production in the tropics. J. Anim. Sci. Biotechnol. 2013, 4, 32. [CrossRef]

2. Twine, R. Emissions from animal agriculture-6.5\% is the new minimum figure. Sustainability 2021, 13, 6276. [CrossRef]

3. Lazarus, O.; McDermid, S.; Jacquet, J. The climate responsibilities of industrial meat and dairy producers. Clim. Chang. 2021, 165, 1-21. [CrossRef]

4. Opio, C.; Gerber, P.; Mottet, A.; Falcucci, A.; Tempio, G.; MacLeod, M.; Vellinga, T.; Henderson, B.; Steinfeld, H. Greenhouse Gas Emissions from Ruminant Supply Chains—A Global Life Cycle Assessment; Food and Agriculture Organization (FAO): Rome, Italy, 2013; p. 214.

5. Pachauri, R.K.; Allen, M.R.; Barros, V.R.; Broome, J.; Cramer, W.; Christ, R.; Church, J.A.; Clarke, L.; Dahe, Q.; Dasgupta, P.; et al Climate Change 2014: Synthesis Report. Contribution of Working Groups I, II and III to the Fifth Assessment Report of the Intergovernmental Panel on Climate Change; IPCC: Geneva, Switzerland, 2014; p. 151.

6. Patra, A.K. Recent advances in measurement and dietary mitigation of enteric methane emissions in ruminants. Front. Vet. Sci. 2016, 3, 39. [CrossRef] [PubMed]

7. Beauchemin, K.A.; Ungerfeld, E.; Eckard, R.J.; Wang, M. Review: Fifty years of research on rumen methanogenesis: Lessons learned and future challenges for mitigation. Animal 2020, 14, s2-s16. [CrossRef] [PubMed]

8. Banik, B.K.; Durmic, Z.; Erskine, W.; Ghamkhar, K.; Revell, C. In vitro ruminal fermentation characteristics and methane production differ in selected key pasture species in Australia. Crop. Pasture Sci. 2013, 64, 935-942. [CrossRef]

9. Wanapat, M.; Kongmun, P.; Poungchompu, O.; Cherdthong, A.; Khejornsart, P.; Pilajun, R.; Kaenpakdee, S. Effects of plants containing secondary compounds and plant oils on rumen fermentation and ecology. Trop. Anim. Health Prod. 2011, 44, 399-405. [CrossRef]

10. Wanapat, M.; Kang, S.; Khejornsart, P. Effects of plant herb combination supplementation on rumen fermentation and nutrient digestibility in beef cattle. Asian-Australas. J. Anim. Sci. 2013, 26, 1127-1136. [CrossRef]

11. Wanapat, M.; Chanthakhoun, V.; Pilajun, R.; Khejornsart, P. Feed resources, rumen fermentation, manipulation and production in swamp buffalo: A review. In The Buffaloes (Bubalus Bubalis)_Production and Research; Presicce, P.A., Ed.; Bentham Science Publishers: Rome, Italy, 2017; pp. 145-179.

12. Patra, A.K.; Park, T.; Kim, M.; Yu, Z. Rumen methanogens and mitigation of methane emissions by anti-methanogenic com-pounds and substances. J. Anim. Sci. Biotechnol. 2017, 8, 13. [CrossRef]

13. Cherdthong, A.; Prachumchai, R.; Wanapat, M. In vitro evaluations of pellets containing Delonix regia seed meal for rumi-nants. Trop. Anim. Health Prod. 2019, 51, 2003-2010. [CrossRef]

14. Wanapat, M.; Khejornsart, P.; Pakdee, P.; Wanapat, S. Effect of supplementation of garlic powder on rumen ecology and digestibility of nutrients in ruminants. J. Sci. Food Agric. 2008, 88, 2231-2237. [CrossRef]

15. Cherdthong, A.; Khonkhaeng, B.; Foiklang, S.; Wanapat, M.; Gunun, N.; Gunun, P.; Chanjula, P.; Polyorach, S. Effects of supplementation of Piper sarmentosum leaf powder on feed efficiency, rumen ecology and rumen protozoal concentration in Thai native beef cattle. Animals. 2019, 9, 130. [CrossRef] [PubMed]

16. Honan, M.; Feng, X.; Tricarico, J.; Kebreab, E. Feed additives as a strategic approach to reduce enteric methane production in cattle: Modes of action, effectiveness and safety. Anim. Prod. Sci. 2021. [CrossRef]

17. AOAC. Official Methods of Analysis, 19th ed.; Association of Official Analytical Chemists: Gaithersburg, MD, USA, 2012.

18. Van Soest, P.; Robertson, J.; Lewis, B. Methods for dietary fiber, neutral detergent fiber, and nonstarch polysaccharides in relation to animal nutrition. J. Dairy Sci. 1991, 74, 3583-3597. [CrossRef]

19. Makkar, H.P.S. Quantification of Tannins in Tree and Shrub Foliage: A Laboratory Manual; Kluwer Academic Publishers: Dordrecht, The Netherlands, 2003; p. 102.

20. Terril, T.H.; Rowan, A.M.; Douglas, G.B.; Barry, T.N. Determination of extractable and bound condensed tannin concentrations in forage plants, protein concentrate meals and cereal grains. J. Sci. Food Agric. 1992, 58, 321-329. [CrossRef] 
21. Menke, K.H.; Steingass, H. Estimation of the energetic feed value obtained from chemical analysis and in vitro gas production using rumen fluid. Anim. Res. Dev. 1988, 28, 7-55.

22. Ørskov, E.R.; McDonald, I. The estimation of protein degradability in the rumen from incubation measurements weighted according to rate of passage. J. Agric. Sci. 1979, 92, 499-503. [CrossRef]

23. Tilley, J.M.A.; Terry, R.A. A two-stage technique for the in vitro digestion of forage crops. Grass Forage Sci. 1963, 18, $104-111$. [CrossRef]

24. Galyean, M. Laboratory Procedure in Animal Nutrition Research; Department of Animal and Food Sciences, Texas Tech University: Lubbock, TX, USA, 1989; p. 192.

25. Tassone, S.; Fortina, R.; Peiretti, P.G. In vitro techniques using the DaisyII incubator for the assessment of digestibility: A review. Animals 2020, 10, 775. [CrossRef]

26. Marius, L.N.; Shipandeni, M.N.T.; Rodríguez-Campos, L.A.; Osafo, E.L.K.; Mpofu, I.D.T.; Ansah, T.; Shiningavamwe, K.L.; Attoh-Kotoku, V.; Antwi, C. Seasonal variation in chemical composition and in-vitro gas production of woody plant species of semi-arid condition of Namibia. Agrofor. Syst. 2021, 95, 1191-1204. [CrossRef]

27. Patra, A.K.; Min, B.-R.; Saxena, J. Dietary tannins on microbial ecology of the gastrointestinal tract in ruminants. Diet. Phytochem. Microbes 2012, 237-262. [CrossRef]

28. Liu, T.; Chen, H.; Bai, Y.; Wu, J.; Cheng, S.; He, B.; Casper, D.P. Calf starter containing a blend of essential oils and prebiotics affects the growth performance of Holstein calves. J. Dairy Sci. 2020, 103, 2315-2323. [CrossRef] [PubMed]

29. Rymer, C.; Huntington, J.; Williams, B.; Givens, D. In vitro cumulative gas production techniques: History, methodological considerations and challenges. Anim. Feed. Sci. Technol. 2005, 123-124, 9-30. [CrossRef]

30. Elberg, K.; Steuer, P.; Habermann, U.; Lenz, J.; Nelles, M.; Südekum, K.-H. A small scale in vitro system for high throughput gas production analysis-A comparison with the Hohenheim gas test. Anim. Feed Sci. Technol. 2018, 241, 8-14. [CrossRef]

31. El-Zaiat, H.; Kholif, A.; Moharam, M.; Attia, M.; Abdalla, A.; Sallam, S. The ability of tanniniferous legumes to reduce methane production and enhance feed utilization in Barki rams: In vitro and in vivo evaluation. Small Rumin. Res. 2020, 193, 106259. [CrossRef]

32. Getachew, G.; Makkar, H.; Becker, K. Tropical browses: Contents of phenolic compounds, in vitro gas production and stoichiometric relationship between short chain fatty acid and in vitro gas production. J. Agric. Sci. 2002, 139, 341-352. [CrossRef]

33. Terranova, M.; Kreuzer, M.; Braun, U.; Schwarm, A. In vitro screening of temperate climate forages from a variety of woody plants for their potential to mitigate ruminal methane and ammonia formation. J. Agric. Sci. 2018, 156, 929-941. [CrossRef]

34. Chen, L.; Bao, X.; Guo, G.; Huo, W.; Xu, Q.; Wang, C.; Li, Q.; Liu, Q. Effects of hydrolysable tannin with or without condensed tannin on alfalfa silage fermentation characteristics and in vitro ruminal methane production, fermentation patterns, and microbiota. Animals. 2021, 11, 1967. [CrossRef]

35. Fagundes, G.M.; Benetel, G.; Carriero, M.M.; Sousa, R.L.M.; Muir, J.P.; Macedo, R.O.; Bueno, I.C.S. Tannin-rich forage as a methane mitigation strategy for cattle and the implications for rumen microbiota. Anim. Prod. Sci. 2021, 61, 26-37. [CrossRef]

36. Min, B.R.; Castleberry, L.; Allen, H.; Parker, D.; Waldrip, H.; Brauer, D.; Willis, W. Associative effects of wet distiller's grains plus solubles and tannin-rich peanut skin supplementation on in vitro rumen fermentation, greenhouse gas emissions, and microbial changes. J. Anim. Sci. 2019, 97, 4668-4681. [CrossRef] [PubMed]

37. Aderinboye, R.Y.; Olanipekun, A.O. An in-vitro evaluation of the potentials of turmeric as phytogenic feed additive for rumen modification. Niger. J. Anim. Prod. 2021, 48, 193-203. [CrossRef]

38. Sarnataro, C.; Spanghero, M.; Lavrenčič, A. Supplementation of diets with tannins from Chestnut wood or an extract from Stevia rebaudiana Bertoni and effects on in vitro rumen fermentation, protozoa count and methane production. J. Anim. Physiol. Anim. Nutr. 2020, 104. [CrossRef]

39. Jayanegara, A.; Leiber, F.; Kreuzer, M. Meta-analysis of the relationship between dietary tannin level and methane formation in ruminants from in vivo and in vitro experiments. J. Anim. Physiol. Anim. Nutr. 2011, 96, 365-375. [CrossRef] [PubMed]

40. Newbold, C.J.; De La Fuente, G.; Belanche, A.; Ramos-Morales, E.; McEwan, N. The role of ciliate protozoa in the rumen. Front. Microbiol. 2015, 6, 1313. [CrossRef] [PubMed]

41. Dai, X.; Faciola, A.P. Evaluating strategies to reduce ruminal protozoa and their impacts on nutrient utilization and animal performance in ruminants-A meta-analysis. Front. Microbiol. 2019, 10, 2648. [CrossRef]

42. Cieslak, A.; Zmora, P.; Pers-Kamczyc, E.; Szumacher-Strabel, M. Effects of tannins source (Vaccinium vitis idaea L.) on rumen microbial fermentation in vivo. Anim. Feed Sci. Technol. 2012, 176, 102-106. [CrossRef]

43. Wang, W.; Wang, S.; Luo, D.; Zhao, X.; Yin, M.; Zhou, C.; Liu, G. Effect of Chinese herbal medicines on rumen fermentation, methanogenesis and microbial flora in vitro. S. Afr. J. Anim. Sci. 2019, 49, 63-70. [CrossRef]

44. Zhou, L.; Wang, D.; Hu, H.; Zhou, H. Effects of Piper sarmentosum extract supplementation on growth performances and rumen fermentation and microflora characteristics in goats. J. Anim. Physiol. Anim. Nutr. 2020, 104, 431-438. [CrossRef] [PubMed]

45. Akanmu, A.M.; Hassen, A. The use of certain medicinal plant extracts reduced in vitro methane production while improving in vitro organic matter digestibility. Anim. Prod. Sci. 2018, 58, 900. [CrossRef]

46. Cieślak, A.; Zmora, P.; Matkowski, A.; Nawrot-Hadzik, I.; Pers-Kamczyc, E.; El-Sherbiny, M.; Bryszak, M.; Szumacher-Strabe, M. Tannins from Sanguisorba officinalis affect in vitro rumen methane production and fermentation. J. Anim. Plant Sci. 2016, 26, $54-62$. 
47. Akanmu, A.M.; Hassen, A.; Adejoro, F.A. Gas production, digestibility and efficacy of stored or fresh plant extracts to reduce methane production on different substrates. Animals 2020, 10, 146. [CrossRef]

48. Kumar, S.; Choudhury, P.K.; Carro, M.D.; Griffith, G.; Dagar, S.S.; Puniya, M.; Calabro, S.; Ravella, S.R.; Dhewa, T.; Upadhyay, R.C.; et al. New aspects and strategies for methane mitigation from ruminants. Appl. Microbiol. Biotechnol. 2013, 98, 31-44. [CrossRef]

49. Min, B.R.; Solaiman, S.; Waldrip, H.M.; Parker, D.; Todd, R.W.; Brauer, D. Dietary mitigation of enteric methane emissions from ruminants: A review of plant tannin mitigation options. Anim. Nutr. 2020, 6, 231-246. [CrossRef] [PubMed]

50. Gunun, P.; Gunun, N.; Cherdthong, A.; Wanapat, M.; Polyorach, S.; Sirilaophaisan, S.; Wachirapakorn, C.; Kang, S. In vitro rumen fermentation and methane production as affected by rambutan peel powder. J. Appl. Anim. Res. 2017, 46, 626-631. [CrossRef]

51. Kang, S.; Wanapat, M.; Cherdthong, A. Effect of banana flower powder supplementation as a rumen buffer on rumen fermentation efficiency and nutrient digestibility in dairy steers fed on high concentrate diet. Anim. Feed Sci. Technol. 2014, 196, 32-41. [CrossRef] 